\title{
THE EFFECT OF STRATEGIC LEADERSHIP STYLE AND GREEN HUMAN RESOURCE MANAGEMENT ON THE MANAGEMENT PERFORMANCE OF KODAM JAYA
}

\author{
Dudung Abdurachman ${ }^{1 凶}$, Willy Arafah ${ }^{2}$, Kusnad ${ }^{3}$ \\ 1,2,3 Faculty of Economics, University Trisakti Jakarta, Indonesia
}

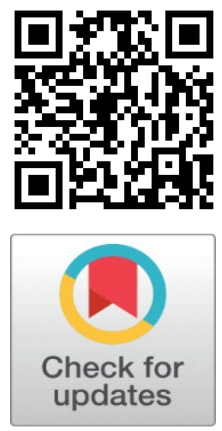

Received 4 December 2021

Accepted 2 January 2022

Published 31 January 2022

\section{CorrespondingAuthor}

Dudung Abdurachman,

dudung.abdurachman1988@gmail.com

DOI

10.29121/granthaalayah.v10.i1.2022 .4485

Funding: This research received no specific grant from any funding agency in the public, commercial, or not-for-profit sectors.

Copyright: (C) 2022 The Author(s). This is an open access article distributed under the terms of the Creative Commons Attribution License, which permits unrestricted use, distribution, and reproduction in any medium, provided the original author and source are credited.

\section{ABSTRACT}

The purpose of this research is to pay attention to environmental developments and dynamic strategic contexts that affect the implementation of national defense. Especially in facing challenges in national defense. In the current Reformation Era, the Commander of the Military Region of Kodam Jaya has many tasks to prevent problems in society, especially in the current pandemic era. The Jaya Regional Military Command is able to maintain stability, establish cooperation with various parties, coordinate to maintain order by disbanding crowds that will bring danger and safety to the state, especially the people of Jakarta.

The research design and method used in this research is hypothesis testing. This research is a quantitative non-experimental, using a questionnaire given to 93 respondents. This research was carried out at the Jaya Regional Military Command. Data analysis using SPSS and PLS.3.29 software with multivariate Structural Equation Model (SEM) analysis method.

The results of this study indicate that: The influence of Strategic Leadership Style, Green Human Resource Management on Management Performance is positive and significant. The influence of Teamwork Management on Performance Management is positive and significant. The influence of Teamwork Management mediating Strategic Leadership Style, Green Human Resource Management on Management Performance is positive and significant. It means that the higher/positive mediation of Teamwork Management on Strategic Leadership Style, Green Human Resource Management, the higher/positive Management Performance. Improvement and development of quality and leadership style must first, pay attention to friendly and cooperative resources.

Theoretical implications: Teamwork Management as mediating for Strategic Leadership Style, and Green Human Resource Management is able to improve Management Performance, by increasing Teamwork Management through increasing its dimensions will be able to improve Management Performance of the Jayakarta Military Regional Command (Kodam Jaya) Central Jakarta.

Keywords: Strategic Leadership Style, Green Human Resource Management, Teamwork Management, Management Performance

\section{INTRODUCTION}

In the life of a country, the defense and security aspect are a very essential factor in ensuring the survival of the country. Without being able to defend itself against threats from abroad and without being able to guarantee security against threats from within, a country will not be able to survive. The Indonesian nation, which proclaimed its independence on August 17, 1945, was determined to defend and defend and uphold the independence and sovereignty of the 
state and nation based on Pancasila and the 1945 Constitution.

In this regard, the government, as directed by the President, has shifted the focus of infrastructure development to human resource development. Observing this, evaluation of the performance of human resources in organizations/institutions is very important for organizational leaders in order to carry out evaluations and plan human resources in the future. The results of the evaluation of the performance of human resources can be used as a basis for determining strategic management actions in order to achieve the goals of the organization/institution that have been set.

The dynamic development of the environment and strategic context affects the implementation of national defence. Especially in facing challenges in national defence. In the current Reformation Era, the Commander of the Military Region of Kodam Jaya has many tasks to prevent problems in society, especially in the current pandemic era. The Jaya Regional Military Command is able to maintain stability, establish cooperation with various parties, coordinate to maintain order by disbanding crowds that will bring danger and safety to the state, especially the people of Jakarta.

The Jaya Regional Military Command requires synergy in carrying out its duties. Synergy has several meanings or definitions but in principle contains the same meaning. According to Maulana (2019), that synergy is an interaction or collaboration between two or more organizations, elements, or agencies to produce a combination of performance results that is greater than the number of results that are done individually. According to Nguyen and Luu (2019), synergy describes how to work in a group. Perform effective problem solving, collaborate in decision making, have different values and build differences-based strengths. It is instilled continuously and when synergy becomes a habit in the group, the results of cooperation will exceed the sum of the results of each member when working alone.

The performance of the Leaders in the ranks of the Indonesian National Armed Forces, especially the High Commander and Echelon Officials, is also a determining factor for the success of the Indonesian Army in supporting the achievement of the government's target to carry out national development programs in the field of Défense and Security.

The Chief of Staff of the Indonesian Army National Army stated that the Indonesian Army National Army is a very strategic organization and plays an important role in maintaining state security and national safety, as well as the sovereignty and territorial integrity of the Unitary State of the Republic of Indonesia. All work units of the Indonesian Armed Forces must continue to synergize and improve performance and performance in supporting all national defence programs. According to the Chief of Staff of the Indonesian Armed Forces, one of the work units whose performance must be stimulated is the institution of the Army, the National Police, and the Regional Government, because the performance of Military Leaders and Local Governments will determine the success of the domestic defence industry in supporting people's security. The Army emphasizes the Leaders and Officers, to improve leadership, motivation and enthusiasm for work, discipline, and responsibility, as well as loyalty and loyalty to organizations, especially the Indonesian Armed Forces.

The research gap found was the placement of the Teamwork Management variable. as a mediator variable, which mediates the factors of Strategic Leadership Style, and Green Human Resource Management, on Management Performance. This can be seen in research. Several previous studies have shown the relationship between management performance and several variables such as Strategic Leadership Style, Green Human Resource Management, and Teamwork 
Management. Rozen-Bakher (2018) found that Green Human Resource Management has a positive correlation with Strategic Leadership Style which further has a significant impact on Teamwork Management, and Teamwork Management is a mediator between Strategic Leadership Style, and Green Human Resource Management. Prima et al. (2020), Chen et al. (2020) found that Competency, and Policy Synergy have a simultaneous effect on Performance. Allen (2015), Maheshwari and Yadav (2019) found that Strategic Leadership Style, and Green Human Resource Management significantly affect Management Performance. Management Performance. This finding implies that all efforts to improve Management Performance should be focused on improving Strategic Leadership Style, and Green Human Resource Management with Teamwork Management mediation.

Novelty in this research is, Teamwork Management, Strategic Leadership Style, and Green Human Resource Management, according to the explanations and findings of previous research, Individual performance, including the performance of defence researchers, can be influenced by a number of factors, either internal or external. comes from within the individual himself, as well as external or comes from outside the individual/in the organizational environment. The important factors in question include Teamwork Management, Strategic Leadership Style, and Green Human Resource Management. However, several previous studies have not integrated the variables Teamwork Management, Strategic Leadership Style, and Green Human Resource in an integrated study, so that the gap becomes a novelty in research.

\section{LITERATURE REFERENCES}

There are several definitions related to strategic leadership that have been put forward in several studies. Khajeh (2018) defines strategic leadership as a person's ability to anticipate, imagine, maintain flexibility, think strategically, and work with others to initiate changes that will create a good future for the organization. Bin Atan and Mahmood (2019) stated that strategic leadership is the ability to influence others to voluntarily make day-to-day decisions that enhance the long-term viability of the organization, while at the same time maintaining short-term financial stability. Alblooshi et al. (2020) defines strategic leadership as the process of forming a vision for the future, communicating that vision to subordinates, stimulating \& motivating followers, and taking part in exchanges that support strategy with colleagues and subordinates. Meanwhile, the definition of strategic leadership according to Khajeh (2018) is a series of processes that determine the extent to which an organization is effective in creating strong connections between people, technology, work processes \& business opportunities that aim to increase economic, social, and intellectual capital for shareholders, community, and employees.

Green Human Resource Management is a development of Human Resource Management, by adding environmental aspects. Green Human Resource Management can be viewed as a complete and integrated Human Resources activity involved in the development, implementation and continuous maintenance of a system, which ensures the employees of an organization can perform effectively, and aims to make the organization's employees green for the benefit of the individual, society, environment, and business Green Human Resource Management consists of all Human Resources practices namely: job position analysis and description, recruitment and selection, training and development, performance and appraisal, as well as rewards which are recognized as important tools to align staff 
with environmental strategy organizations in the field of human resource management Several researchers have defined green human resource management in their literature as the integration of corporate environmental management into human resource management Singh (2020), Islam et al. (2020)

\section{METHODOLOGY}

This research will use survey techniques, deductive and quantitative approaches Yusup (2018). The deductive approach aims to test theories through collecting data from respondents and then applying them and observing them with statistical tests. The quantitative method focuses on collecting data according to the problem and the number of populations and data analysis. This study is a testing hypothesis, which aims to explain the nature of the relationship between two or more variables

Population, the sample used is 135 people. The sampling technique is purposive sampling with the criteria of individuals who meet the requirements to be selected as respondents are those who meet the following criteria:

1) The current position in the military organization where you serve is the minimum as a policy maker.

2) Minimum five years working experience in Military Défense.

3) The current length of service is a minimum of two years.

4) Education Diploma, Strata one or equivalent in the field of defence/military.

The above criteria are made with the assumption that the respondent already has sufficient and relevant knowledge of the defence organization. In addition, it is also assumed that the respondent is sufficiently familiar with the object of research so that data related to the object of research can be obtained through the respondent.

The criteria for determining the number of samples are based on considerations of the use of the analytical tools to be used. In this study, we will use a structural equation model or Structural Equation Modelling (SEM) as an analysis. The minimum sample size of 100 will be used as a benchmark referring to Hair et al. (2019) which states that the minimum sample size of 100 is sufficient to be used to estimate the model.

Descriptive statistics is a process that can be carried out in research data in tabulated form so that it can be easily understood and interpreted. Descriptive statistical data analysis aims to analyse data by summarizing and describing numerical data regarding gender, age, status, position. Manurung (2018).

Based on the results of descriptive analysis of respondents' data based on gender who participated in the study in Table 1.

\begin{tabular}{|ccc|}
\hline \multicolumn{3}{c}{ Table 1 Respondent Data Based on Gender } \\
\hline Gender & Frequency & Percentage \\
\hline Man & 91 & $97,8 \%$ \\
\hline Woman & 2 & $2,2 \%$ \\
Total & $\mathbf{9 3}$ & $\mathbf{1 0 0 \%}$ \\
\hline
\end{tabular}

Source: Processed data (2021)

Table 1 shows that there are 91 male respondents (97.8\%) and 2 female respondents $(2.2 \%)$. These results indicate that there are more men serving on the Officers and Staff of the Jayakarta Military Regional Command, 051 Wijayakarta Military Regiment Command, 052 Wijayakrama Military Regiment Command and 
0501 Central Jakarta Military District Command compared to women. Respondent data based on age in Table 2

\begin{tabular}{|ccc|}
\hline Table 2 & Respondent Data by Age \\
\hline Age & Frequency & Percentage \\
\hline 21- 30 & 0 & $\%$ \\
\hline 31- 40 & 4 & $4,3 \%$ \\
\hline 41- 50 & 54 & $58,1 \%$ \\
\hline 51- $\mathbf{6 0}$ & 35 & $37,6 \%$ \\
\hline $\mathbf{6 0}$ ke atas & 0 & $0 \%$ \\
\hline Total & $\mathbf{9 3}$ & $\mathbf{1 0 0} \%$ \\
\hline
\end{tabular}

Source: Processed data (2021)

Table 2 shows that the age of 31-40 (4.3\%) with 4 respondents showing an undeveloped career age, age 41-50 (58.1\%) showing the maturity of echelon officials as many as 54 officials were at this age the career and positions are entering a very productive period and are in a very good process, followed by the age of 51-60 (37.6\%) with 35 people, the age that is very starting to enter retirement period in work because a long career is very developed and reaching the top position which shows that decision makers are very well established and at a very mature age to demonstrate the quality of work, especially as Officers and Staff of the Jayakarta Military Regional Command, 051 Wijayakarta Military Regiment Command, Military Regiment Command 052 Wijayakrama and the Military District Command 0501 Central Jakarta. Respondents in this study also have different levels of education. Respondent data based on education Table 3

\begin{tabular}{|ccc|}
\hline \multicolumn{3}{c}{ Table 3 Respondent Data Based on Education } \\
\hline Education & Frequency & Percentage \\
\hline Senior High Scholl & 0 & $0 \%$ \\
\hline Diploma & 10 & $10,8 \%$ \\
\hline Bachelor & 46 & $49,5 \%$ \\
\hline Magister & 37 & $39.80 \%$ \\
\hline Doctoral & 0 & $0 \%$ \\
\hline Total & $\mathbf{9 3}$ & $\mathbf{1 0 0 \%}$ \\
\hline Source: Processed data (2021) & \\
\hline
\end{tabular}

Table 3 shows that the education level of respondents who graduated from senior high no longer means that all decision-making officials have a very good level of education. Diploma/D3 as many as 10 people (10.8\%) graduated and Bachelor as many as 46 people (49.5\%). 37 people (39.8\%) Masters and no Doctoral program education shows the quality of the leaders and staff of the Jayakarta Military Regional Command, 051 Wijayakarta Military Regiment Command, Military Regiment Command 052 Wijayakrama and the Military District Command 0501 Central Jakarta, have a very good level of education, where the number of bachelors and masters is balanced.

Decision makers continue to improve their ability to analyze and make good contributions to the Jayakarta Military Regional Command, Military Regiment Command 051 Wijayakarta, Military Regiment Command 052 Wijayakrama and Military District Command 0501 Central Jakarta , is also getting better, especially in the use of strategy based on education, especially in the field of military defence and this level of education shows the ability of the strategic division, especially officials 
and staff to be able to analyse the concept and development of the Jayakarta Military Regional Command, Military Regiment Command 051 Wijayakarta, Military Regiment Command 052 Wijayakrama and Military District Command 0501 Central Jakarta. Furthermore, respondent data is based on position.

\section{RESULT AND DISCUSSION}

Evaluation of the measurement model or outer model begins by testing the convergent validity (convergent validity) and discriminant validity (discriminant validity). Measurement model of the validity of the PLS Algorithm Strategic Leadership Style.

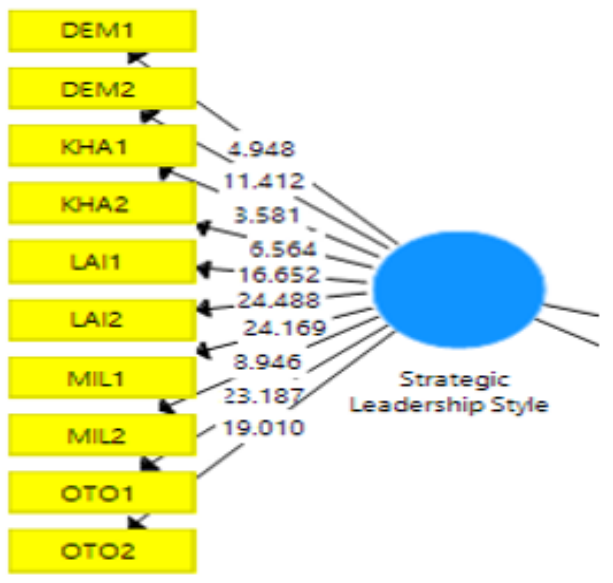

Figure 1 Display of the results of the PLS Algorithm Strategic Leadership Style

The results of the convergent validity test for each indicator are declared valid because the test value for the loading factor is 0.5 and the AVE value is above 0.5. The results of the reliability test to see the value of Cronbach's alpha and composite reliability. The requirements for the value of Cronbach's alpha and composite reliability are 0.7 . The results of reliability testing in Table 4

\begin{tabular}{|c|c|c|c|}
\hline \multicolumn{4}{|c|}{ Table 4 Reliability Test Results } \\
\hline Variable & Dimension & $\begin{array}{l}\text { Cronbachs } \\
\text { Alpha }\end{array}$ & $\begin{array}{l}\text { Composite } \\
\text { Reliability }\end{array}$ \\
\hline $\begin{array}{c}\text { Strategic } \\
\text { Leadership Style. }\end{array}$ & $\begin{array}{c}\text { Otokratik Militeristik Laissez-faire } \\
\text { Kharismatik Demokratik }\end{array}$ & 0.872 & 0.898 \\
\hline $\begin{array}{l}\text { Green Human } \\
\text { Resource } \\
\text { Management }\end{array}$ & $\begin{array}{c}\text { Green analysis and description of jobs, } \\
\text { Green Recruitment Green Performance } \\
\text { assessment green rewards green selection } \\
\text { green training }\end{array}$ & 0.874 & 0.899 \\
\hline $\begin{array}{l}\text { TeamWork } \\
\text { Management }\end{array}$ & Responsible Contribute Ability & 0.774 & 0.836 \\
\hline $\begin{array}{l}\text { Management } \\
\text { Performance }\end{array}$ & $\begin{array}{l}\text { Feedback Compensation Communication } \\
\text { Reward }\end{array}$ & 0.824 & 0.864 \\
\hline
\end{tabular}

Source: Processed data (2021)

Based on the analysis that has been carried out, the discussion of the hypothesis is presented as follows:

H1. Strategic Leadership Style has a T-Statistic value of $2.574>1.96$ and a PValue of $0.010<0.050$. This figure shows that Strategic Leadership Style has a significant positive effect on Management Performance. 
H2. Green Human Resource Management has a T-Statistic value of $12.609>$ 1.96 and a P-Value of $0.000<0.050$. This figure shows that Green Human Resource Management has a significant positive effect on Management Performance.

H3. Strategic Leadership Style has a T-Statistic value of $2.695>1.96$ and a PValue of $0.000<0.050$. This figure shows that Strategic Leadership Style has a significant positive effect on Teamwork Management.

H4. Green Human Resource Management has a T-Statistic value of $2.752>1.96$ and a P-Value of $0.006<0.05$. This figure shows that Green Human Resource Management has a significant positive influence on Teamwork Management.

H5. Teamwork Management has a T-Statistic value of $2.887>1.96$ and a PValue of $0.004<0.050$. This figure shows that Teamwork Management has a significant positive effect on Management Performance.

According to Andrades and Dimanche (2019) that human resource development is important to be able to produce superior leaders; believes that the formulation of the vision and mission will determine the progress of the Jayakarta Military Regional Command and believes that the governance of the Jayakarta Military Regional Command will affect the achievement of strategic objectives; the more respondents feel they are 'part of the family' in the work unit; worry about what might happen if you change jobs without someone to replace you; and have a strong sense of belonging to the work unit. In particular at the Jayakarta Military Regional Command, the 051 Wijayakarta Military Regiment Command, the 052 Wijayakrama Military Regiment Command and the 0501 Central Jakarta Military District Command.

\section{CONCLUSION}

The results of this study provide a conclusion that in general Strategic Leadership Style, Green Human Resource Management are variables that affect Teamwork Management as a mediating variable. Likewise, Teamwork Management has a good influence on Management Performance, this result also affects the Teamwork Management variable as a mediation for the Strategic Leadership Style variable, Green Human Resource Management has a strong influence on Management Performance, especially at the Jayakarta Military Regional Command (Kodam Jaya), Central Jakarta. Conclusions based on the objectives in this study are as follows:

1) There is an influence of Strategic Leadership Style on the Performance Management of Kodam Jaya, the meaning of this positive influence states that the Strategic Leadership Style, which is accepted can give a positive reaction to Performance Management, especially at the Jayakarta Military Regional Command, 051 Wijayakarta Military Regiment Command, 052 Military Regiment Command Wijayakrama and the Military District Command 0501 Central Jakarta. The most dominant dimensions are militaristic and charismatic with the main indicator being the leadership inviting the staff with ideas and opinions to express their wishes, then the leaders are very liked by the staff because they are able to give appreciation to those below. Alblooshi et al. (2020).

2) There is an influence of Green Human Resource Management on the Management Performance of Kodam Jaya, the meaning of this positive influence states that the received Green Human Resource Management can give a positive reaction to the Management Performance. This influence shows that the Green Human Resource Management is positive and 
significant to the Management Performance. The most dominant in green selection with the main indicator being the recruitment carried out by the organization is the selection of positions based on the performance of the organization, so that the selection for leadership is always discussed by the Jayakarta Military Regional Command (Kodam Jaya) organization, Central Jakarta. Andrades and Dimanche (2019).

3) There is an influence of Strategic Leadership Style on Teamwork Management. The meaning of this positive influence states that the Strategic Leadership Style, which is accepted, can give a positive reaction to Teamwork Management. Leadership style has an effect on Teamwork Management in Jayakarta Military Regional Command Employees, Jayakarta Military Regional Command. The influence of Leadership Style on Teamwork Management is positive and significant, with the most dominant dimension of Leadership Style being the militaristic leadership dimension. Indicators of the leadership using a command system to its staff, the leadership is hard on the staff and always obedient and formal. This shows that the leadership style, especially the militaristic dimension, will result in an increase in the cooperation of every soldier in the Jayakarta Military Regional Command. Alblooshi et al. (2020)

4) There is an influence of Green Human Resource Management on Teamwork Management, the meaning of this positive influence states that the received Green Human Resource Management can give a positive reaction to Teamwork Management. This effect shows that Green Human Resource Management is positive and significant. The most dominant dimension is Green Rewards, on indicators of leadership and staff who excel and are environmentally friendly will be given awards, and the awards given are in the form of promotions and class. This will have a very good influence on the Teamwork Management of the Jayakarta Military Regional Command (Kodam Jaya). Andrades and Dimanche (2019)

5) There is an influence of Teamwork Management on the Management Performance of Kodam Jaya, the meaning of this positive influence states that Teamwork Management, which is accepted can give a positive reaction to Performance Management, especially at the Jayakarta Military Regional Command, 051 Wijayakarta Military Regiment Command, 052 Wijayakrama Military Regiment Command and Military District Command 0501 Central Jakarta. Cooperation between superiors and staff can be well established, especially in the contribution dimension to indicators where a contribution to reach an agreement through deliberation will provide maximum results and create good cooperation between leaders and staff for the advancement of the Jayakarta Military Regional Command (Kodam Jaya). Andrades and Dimanche (2019), Alblooshi et al. (2020).

Based on the results of the research conducted, the theoretical implications related to the development of the theory of leadership style and environmentally friendly resources from the Strategic Leadership Style, and Green Human Resource Management on Performance Management mediated by Teamwork Management at the Jayakarta Military Regional Command (Kodam Jaya), are as follows: the following: Strategic Leadership Style, and Green Human Resource Management The results of this study strengthen the positive and significant influence. Strategic Leadership Style, and Green Human Resource Management on Performance Management mediated by Teamwork Management at the Jayakarta Military 
Regional Command (Kodam Jaya), in line with previous research. Kajzer and Walinga (2017), Andrades and Dimanche (2019), Meerits and Kivipõld (2020)

Managerial implications, can improve strategy and organizational performance, military officials and echelons, must pay attention to factors including: This research shows that leadership style and strategy greatly affect personnel cooperation, then improvement and ability and strategy through increasing each dimension will have a significant effect It's good for every step the leaders develop military organizations to become models to move forward and provide opportunities for personnel so that they can build strong teamwork for the betterment of the organization. Leaders, need to maintain the things that are already good and improve the things that are still lacking in an effort to increase the effectiveness of the Leadership Style.

Leaders, need to maintain things that are already good and improve things that are still lacking in an effort to increase Job Satisfaction. The things that must be maintained to increase Job Satisfaction are such as: a positive thing is giving awards in an apple in front of all members; employees carry out specific problem solving, and leaders always provide assistance to members' limitations in completing their work.

Leaders, need to maintain things that are already good and improve things that are still lacking in an effort to increase Job Satisfaction. The things that must be maintained to increase Job Satisfaction are such as: a positive thing is giving awards in an apple in front of all members; employees carry out specific problem solving, and leaders always provide assistance to members' limitations in completing their work; have performed their duties according to the workload in their respective positions; and have the ability and expertise in accordance with the workload in completing analysis and assessment work. Leaders, need to maintain things that are already good and improve things that are still lacking in an effort to improve Organizational Performance. Especially the Jayakarta Military Regional Command area.

\section{REFERENCES}

Al Khajeh, E. H. (2018). Leadership styles on organizational performance. Journal of Human Reseources Management Research. Retrieved from https://doi.org/10.5171/2018.687849

Alblooshi, M., Shamsuzzaman, M., \& Haridy, S. (2020). The relationship between leadership styles and organisational innovation: A systematic literature review and narrative synthesis. In European Journal of Innovation Management. Retrieved from https://doi.org/10.1108/EJIM-11-2019-0339

Allen, C. D. (2015). Ethics and Army Leadership : Climate Matters. Parameters.

Andrades, L., \& Dimanche, F. (2019). Destination competitiveness in Russia: tourism professionals' skills and competences. International Journal of Contemporary Hospitality Management, 31(2), 910-930. Retrieved from https://doi.org/10.1108/IJCHM-11-2017-0769

Bin Atan, J., \& Mahmood, N. H. N. (2019). The role of transformational leadership style in enhancing employees' competency for organization performance. Management Science Letters. Retrieved from https://doi.org/10.5267/j.msl.2019.7.033

Chen, M. Y. C., Lam, L. W., \& Zhu, J. N. Y. (2020). Should companies invest in human resource development practices ? The role of intellectual capital and 
organizational performance improvements. Personnel Review. Retrieved from https://doi.org/10.1108/PR-04-2019-0179

Hair, J. F., Risher, J. J., Sarstedt, M., \& Ringle, C. M. (2019). When to use and how to report the results of PLS-SEM. In European Business Review. Retrieved from https://doi.org/10.1108/EBR-11-2018-0203

Islam, T., Khan, M. M., Ahmed, I., \& Mahmood, K. (2020). Promoting in-role and extrarole green behavior through ethical leadership : mediating role of green HRM and moderating role of individual green values. International Journal of Manpower. Retrieved from https://doi.org/10.1108/IJM-01-2020-0036

Kajzer Mitchell, I., \& Walinga, J. (2017). The creative imperative: The role of creativity, creative problem solving and insight as key drivers for sustainability. Journal of Cleaner Production. Retrieved from https://doi.org/10.1016/j.jclepro.2016.09.162

Maheshwari, S. K., \& Yadav, J. (2019). The role of HR in leadership development. Development and Learning in Organizations, 33(5), 20-23. Retrieved from https://doi.org/10.1108/DLO-11-2018-0141

Manurung, H. (2018). The Impact of Global Culture toward Local Wisdom: A Study on Multiculturalism \& Mass Media. 1-16. Retrieved from https://papers.ssrn.com/sol3/papers.cfm?abstract_id=3132736

Maulana, S. (2019). Sinergitas Pemerintah, Masyarakat dan Dunia Usaha dalam Pemberdayaan Usaha Kecil untuk Mewujudkan Pembangunan Nasional. November. Retrieved from https://www.researchgate.net/profile/Syahrial-

Maulana/publication/336987987_Sinergitas_Pemerintah_Masyarakat_dan _Dunia_Usaha_dalam_Pemberdayaan_Usaha_Kecil_untuk_Mewujudkan_Pe mbangunan_Nasional/links/5dbd9dd7299bf1a47b0ebb67/SinergitasPemerintah-Masyarakat-dan-Dunia-Usaha-dalam-Pemberdayaan-UsahaKecil-untuk-Mewujudkan-Pembangunan-Nasional.pdf

Meerits, A., \& Kivipõld, K. (2020). Leadership competencies of first-level military leaders. Leadership and Organization Development Journal, 41(8), 953-970. Retrieved from https://doi.org/10.1108/LODJ-09-2019-0392

Nguyen, T. T. N., \& Luu, T. M. N. (2019). Linking transformational leadership and organizational performance : An empirical investigation of manufacturing firms in Vietnam. Economics and Sociology, 12(2), 170-191. Retrieved from https://doi.org/10.14254/2071-789X.2019/12-2/10

Prima Lita, R., Fitriana Faisal, R., \& Meuthia, M. (2020). Enhancing small and medium enterprises performance through innovation in Indonesia : A framework for creative industries supporting tourism. Journal of Hospitality and Tourism Technology, 11(1), 155-176. Retrieved from https://doi.org/10.1108/JHTT-11-2017-0124

Rozen-Bakher, Z. (2018). The trade-off between synergy success and efficiency gains in M\&A strategy. EuroMed Journal of Business, 13(2), 163-184. Retrieved from https://doi.org/10.1108/EMJB-07-2017-0026

sSingh, S. (2020). An assessment in the green HRM practices and environmental ssustainability- A review of literature. International Journa of Management, Scopus Indexed.

Yusup, F. (2018). Uji Validitas dan Reliabilitas Instrumen Penelitian Kuantitatif. Jurnal Tarbiyah: Jurnal Ilmiah Kependidikan. Retrieved from https://doi.org/10.18592/tarbiyah.v7i1.2100 